\title{
Age, Conditions of Formation, and Fluid Composition of the Pervomaiskoe Molybdenum Deposit (Dzhidinskoe Ore Field, South-Western Transbaikalia, Russia)
}

\author{
Ludmila B. Damdinova ${ }^{1,2, *}$, Bulat B. Damdinov ${ }^{1,2, *}$, Xiao-Wen Huang ${ }^{3}$, Nikolay V. Bryansky ${ }^{4}$, \\ Valentin B. Khubanov ${ }^{1,2}$ and Denis S. Yudin ${ }^{5}$ \\ 1 Geological Institute, Siberian Branch of the Russian Academy of Sciences, Sakh'yanovoi st. 6a, \\ 670047 Ulan-Ude, Russia; khubanov@mail.ru \\ 2 Buryat State University, Smolina St, d. 24 “a”, 670000 Ulan-Ude, Russia \\ 3 Institute of Geochemistry, Chinese Academy of Sciences, 99 West Lincheng Road, Guanshanhu District, \\ Guiyang 550081, China; huangxiaowen@vip.gyig.ac.cn \\ 4 Vinogradov Institute of Geochemistry, Siberian Branch of the Russian Academy of Sciences, Favorskogo st. 1 \\ “A", 664033 Irkutsk, Russia; tridigron@yandex.ru \\ 5 VS Sobolev Institute of geology and mineralogy Siberian Branch of Russian Academy of sciences, Pr-t \\ Akademika Koptyuga 3, 630090 Novosibirsk, Russia; yudin@igm.nsc.ru \\ * Correspondence: ludamdinova@mail.ru (L.B.D.); damdinov@mail.ru (B.B.D.)
}

Received: 1 August 2019; Accepted: 18 September 2019; Published: 20 September 2019

\begin{abstract}
The article discusses the composition of studied ore-forming solutions and the P-T conditions of molybdenum mineralization in the Pervomaisky stockwork deposit which is situated within the Dzhidinsky ore field (South-Western Transbaikalia, Russia). New geochronological data of zircons from granites, muscovite, and molybdenite from the ore zones indicates the association of the granite formation and ore deposition processes which occurred 119-128 million years ago. Quartz-molybdenite veins of the Pervomaisky deposit were formed at the temperature of $\geq 314$ $186{ }^{\circ} \mathrm{C}$ with some boiling periods. Fluid inclusions in these veins have total salt concentration of 6.3-12.7 wt. \% NaCl equivalent (eq. $\mathrm{NaCl}$ ). The salt solution is composed of chlorides of $\mathrm{Na}, \mathrm{Ca}, \mathrm{K}$, and $\mathrm{Fe}$. The gas phase contains $\mathrm{CO}_{2}, \mathrm{CH}_{4}$, and $\mathrm{N}_{2}$. A series of elements were determined in fluid inclusions by laser ablation (LA)-ICP-MS: Li, Be, B, F, Na, Mg, Al, Cl, K, Ca, Mn, Fe, Cu, Zn, Nb, Mo, $\mathrm{Ag}, \mathrm{Sn}, \mathrm{La}, \mathrm{Ce}, \mathrm{Ta}, \mathrm{W}, \mathrm{Au}, \mathrm{Pb}, \mathrm{Th}, \mathrm{U}$. The Mo content reaches 559 ppm (average of $228 \pm 190$ ppm) in high-grade quartz-molybdenite veinlets, whereas Mo content is up to 212 ppm (average of $25 \pm$ $29 \mathrm{ppm}$ ) in the low-grade veinlets. High-grade veinlets were formed by near-neutral solutions with a higher content of Mo, S, and F, while relatively low-grade veinlets were deposited from alkaline solutions. Our results demonstrate the $\mathrm{pH}$ of the solutions as one of the key factors for ore deposition.
\end{abstract}

Keywords: Mo-W deposits; Pervomaiskoe molybdenum deposit; fluid inclusions; LA-ICP-MS; metal-bearing solutions; isotope dating

\section{Introduction}

In the South-Western Transbaikalia (Russia), there are numerous economic Mo-W deposits that constitute the Dzhidinskoe ore field (N 50 $19^{\prime} ; \mathrm{E} 103^{\circ} 21^{\prime}$ ). This ore field includes Pervomaiskoe Mo, Inkurskoe W, and Kholtosonskoe $\mathrm{W}$ deposits and is characterized by a large metal resource spreading over a relatively small area [1]. The three deposits are unique geological objects and are the largest sources of W and Mo in Russia. All the deposits are genetically related to a single porphyry granitoid intrusion (Pervomaisky stock) [2]. 
Formation of the stockwork Mo-W mineralization occurred during several hydrothermal stages which were separated in time by intrusive magmatism [3]. First, the Mo stockwork representing the Pervomaiskoye molybdenum deposit formed along with minor Mo-Be mineralization. After wards the stockwork of hubnerite-bearing veinlets in the Inkurskoe tungsten deposit formed. This was followed by the formation of the stockwork of hubnerite-bearing veinlets in the Inkurskoe tungsten deposit. The latest stage of ore formation is represented by quartz-hubnerite veins of the Kholtosonskoe tungsten deposit [4].

The quartz-molybdenite veinlets are the oldest among the ore veinlets of the Dzhidinskoe Mo-W (Be) ore field; therefore, studying the P-T-X parameters of ore formation and metal content in ore fluids will allow reconstruction of the early evolution stages of the Dzhidinskoe magmatic-hydrothermal ore system.

Information about key controlling factors for the formation of the stockwork (greisen) W-Mo (Be) deposit is incomplete and fragmentary. In particular, this concerns data on the age of mineralization, fluid, gas, and salt composition, P-T-X parameters of the ore deposition, as well as the metal content of solutions producing vein-stockwork W-Mo (Be) mineralization. Therefore, it is necessary to conduct isotopic dating and fluid inclusion study of such ore deposits in order to obtain ore formation conditions and composition of the Mo-bearing fluids, which are the main controlling factors of ore deposition. In addition, the age determination is also key to understanding the relationship between ore formation and magmatism.

\section{Methods}

Mineralogical and petrographic investigations were carried out using the OLYMPUS BX-51 polarization microscope with a MicroPublisher 3.3 RTV digital camera. Chemical composition of the minerals was determined using a scanning electronic LEO-1430VP microscope with an energy-dispersive INCA Energy 350 spectrometer at the "Analytical center of mineralogical, geochemical and isotope studies" at the Geological Institute of the Siberian Branch of the Russian Academy of Sciences (Ulan-Ude, Russia).

To clarify the scale and nature of interaction between the ore-hosting granites and solutions flowing through the cracks, a sample of granite containing veinlets was cut into a series of plates parallel to the veinlets, each of the plates being $10 \mathrm{~mm}$ wide. The samples weighed 30-40 $\mathrm{g}$ and they were analyzed for 11 main oxides and 16 ore elements $(\mathrm{Mo}, \mathrm{W}, \mathrm{Sn}, \mathrm{Be}, \mathrm{Cu}, \mathrm{Zn}, \mathrm{Pb}, \mathrm{Ag}, \mathrm{Bi}, \mathrm{Co}, \mathrm{Ni}, \mathrm{V}$, $\mathrm{Mn}, \mathrm{Fe}$ ). Thus, we studied the distribution of chemical elements in granites that are in direct contact with the veinlets and up to $30 \mathrm{~cm}$ away from them.

\subsection{U-Pb Dating}

We carried out U-Pb dating of zircon from granites of the Pervomaisky massif using laser ablation sector field inductively coupled plasma mass spectrometry (LA-SF-ICP-MS). Twenty zircon grains were analyzed in 24 points. The U-Pb zircon dating was performed by at the "Analytical center of mineralogical, geochemical and isotope studies" of the Geological Institute of the Siberian Branch of the Russian Academy of Sciences (Ulan-Ude, Russia). Laser ablation was conducted using a UP-213 (New Wave Research) laser ablation system. Isotope analysis of laser-vaporized zircon substance was performed on a Thermo Scientific Element XR single collector sector-field ICP mass spectrometer. Detailed description of the analytical technique and parameters of the procedure was published in [5,6]. Data of mass-spectrometric analysis were processed using the GLITTER software [7] and ISOPLOT macros [8]. 91,500 reference zircon (1065 Ma) [9] was used as an external calibration standard, whereas Plešovice (337 Ma) [10] and GJ-1 [11] reference zircons were used as secondary standards. The analytical errors of ratios in the secondary standard ranged between 1 to $3 \%$ for ${ }^{208} \mathrm{~Pb} /{ }^{232} \mathrm{Th}, 2-3 \%$ for ${ }^{207} \mathrm{~Pb} /{ }^{206} \mathrm{~Pb}, 1-2.5 \%$ for ${ }^{206} \mathrm{~Pb} /{ }^{238} \mathrm{U}$, and ${ }^{207} \mathrm{~Pb} /{ }^{235} \mathrm{U}$ respectively. The values of the concordant ages of Plešovice and GJ-1 zircons were calculated up to less than $2 \%$ on their certified age values. 


\section{2. ${ }^{40} \mathrm{Ar} /{ }^{\beta 9}$ Ar Dating}

${ }^{40} \mathrm{Ar} /{ }^{39} \mathrm{Ar}$ dating of the muscovite was used to determine the age of the ore-bearing quartz veinlets. Isolation of muscovite monomineral fractions was carried out using standard methods of magnetic and density separation. The center for collective use of multielement and isotope studies of the Institute of Geology and Mineralogy of the Siberian Branch of the Russian Academy of Sciences (Novosibirsk, Russia) conducted the ${ }^{40} \mathrm{Ar} /{ }^{39} \mathrm{Ar}$ isotope studies using the step heating method according to the previously published technique [12]. Dating results were calibrated using international standard samples of MCA-11 muscovite (311.0 $\pm 1.5 \mathrm{Ma})$, LP-6 biotite, and Bern-4m muscovite [13]. Samples were wrapped in an aluminum foil, placed in a quartz ampoule, and sealed off after air was pumped out. Then, the samples were irradiated in the cadmium channel of the scientific reactor of the BBP-K type at the Physics and Technology Institute of the Tomsk Polytechnic University (Tomsk, Russia). The neutron flux gradient did not exceed $0.5 \%$ in the sample size. Step heating experiments were carried out in a quartz reactor with an external heating furnace. The blank testing defining ${ }^{40} \mathrm{Ar}(10 \mathrm{~min}$ at $1200^{\circ} \mathrm{C}$ ) did not exceed $5 \times 10^{-10} \mathrm{ncm}^{3}$. Argon was purified by using ZrAl-SAES getters. The isotopic composition of argon was measured with the help of a Noble gas 5400 mass spectrometer (Micromass, England). Measurement errors correspond to the interval $\pm 1 \sigma$. The following coefficients were used to correct for interfering argon isotopes formed during irradiation on $\mathrm{Ca}, \mathrm{Cl}, \mathrm{K}:\left({ }^{39} \mathrm{Ar} /{ }^{37} \mathrm{Ar}\right)_{\mathrm{Ca}}=0.000891$ $\pm 0.000003,\left({ }^{36} \mathrm{Ar} /{ }^{37} \mathrm{Ar}\right)_{\mathrm{Ca}}=0.000446 \pm 0.000004,\left({ }^{40} \mathrm{Ar} /{ }^{39} \mathrm{Ar}\right)_{\mathrm{K}}=0.089 \pm 0.001$. Before measurements, preliminary degassing of the samples was carried out at the temperature of $350{ }^{\circ} \mathrm{C}$. To control the isotope discrimination of the mass spectrometer, portions of purified atmospheric argon were regularly measured. The average value of the ratio ${ }^{40} \mathrm{Ar} /{ }^{36} \mathrm{Ar}$ for the measurement period was $299 \pm 1$. When interpreting the age and $\mathrm{Ca} / \mathrm{K}$ spectra, we used the age plateau method in which the average weighted age is calculated for several consecutive (at least three) temperature steps with consistent age values close to the $\mathrm{Ca} / \mathrm{K}$ ratios. The share of allocated ${ }^{39} \mathrm{Ar}$ corresponding to the plateau should be at least $50 \%$.

\subsection{Re-Os Dating}

Molybdenite Re-Os dating was performed at the State Key Laboratory of Ore Deposit Geochemistry, Institute of Geochemistry, Chinese Academy of Sciences (Guiyang, China), on an ELAN DRC-e inductively coupled plasma-mass spectrometry (ICP-MS) instrument. The detailed analytical technique is described in [14].

\subsection{Fluid Inclusion Study Methods}

Fluid inclusions (FIs in further text) in quartz and fluorite were investigated by the methods of thermometry, cryometry, volumetry, and Raman spectroscopy. To determine the temperature of common homogenization, eutectic temperature and ice melting temperature of aqueous solutions, temperatures of dissolution of daughter phases, a THMSG-600 microthermocamera of the Linkam brand with a temperature measuring range of -196 to $+600{ }^{\circ} \mathrm{C}$ was used. The standard instrumental measurement error is \pm 0.1 in the negative and $\pm 5^{\circ} \mathrm{C}$ in the positive temperature range. A rough estimate of the salt content in the inclusions was calculated based on the ice melting temperature by using a two-component water-salt system $\left(\mathrm{NaCl}-\mathrm{H}_{2} \mathrm{O}\right)$ through the equivalent of $\mathrm{NaCl}$ [15]. The predominant salt in the aqueous solution of inclusions was determined based on the temperature of the eutectic which characterizes the water-salt system [16].

Gas composition of individual FIs was determined using Raman spectroscopy at the Institute of Geology and Mineralogy of the Siberian Branch of the Russian Academy of Sciences (Novosibirsk, Russia). A single-channel LabRam HR 800 Raman-spectrometer with a Horiba Scientific Symphony II semiconductor detector and an Olympus BX-41 confocal microscope was used. The CVI MellesGirot laser with a wavelength of $514 \mathrm{~nm}$ and an output power of 50-30 mW was used for excitation. 
Metal content analysis of ore-forming solutions was carried out by the LA-ICP-MS using a NexION 300D mass spectrometer coupled with an NWR-213 laser ablation platform at the Institute of Geochemistry of the Siberian Branch of the Russian Academy of Sciences (Irkutsk, Russia). NIST-610 glass was used as an external standard. The concentrations of a wide range of elements including $\mathrm{Li}$, $\mathrm{Be}, \mathrm{B}, \mathrm{F}, \mathrm{Na}, \mathrm{Mg}$, Al, Cl, K, Ca, Mn, Fe, Cu, Zn, Nb, Mo, Ag, Sn, La, Ce, Ta, W, Au, Pb, Th, and U, were determined in individual FIs. Detection limits are presented in the Table 1. The calculation of element content in ore-forming solutions was carried out according to the method described by A.A. Borovikov et al. [17].

Table 1. Detection limits of LA-ICP-MS analysis.

\begin{tabular}{ccccccccccccccc}
\hline Element & $\mathbf{L i}$ & $\mathbf{B e}$ & $\mathbf{B}$ & $\mathbf{F}$ & $\mathbf{N a}$ & $\mathbf{M g}$ & $\mathbf{A l}$ & $\mathbf{S i v}$ & $\mathbf{C l}$ & $\mathbf{K}$ & $\mathbf{C a}$ & $\mathbf{M n}$ & $\mathbf{F e}$ & $\mathbf{C u}$ \\
\hline Mass & 7 & 9 & 11 & 19 & 23 & 24 & 27 & 28 & 35 & 39 & 44 & 55 & 57 & 63 \\
DL, ppm & 200 & 23 & 70 & 3000 & 300 & 10 & 30 & 36 & 500 & 70 & 16,000 & 23 & 100 & 7 \\
RSD, \% & 50 & 50 & 50 & 50 & 10 & 20 & 12 & 14 & 50 & 50 & 17 & 18 & 50 & 15 \\
\hline Element & $\mathbf{Z n}$ & $\mathbf{Z r}$ & $\mathbf{N b}$ & $\mathbf{M o}$ & $\mathbf{A g}$ & $\mathbf{S n}$ & $\mathbf{L a}$ & $\mathbf{C e}$ & $\mathbf{T a}$ & $\mathbf{W}$ & $\mathbf{A u}$ & $\mathbf{P b}$ & $\mathbf{T h}$ & $\mathbf{U}$ \\
\hline Mass & 66 & 90 & 93 & 98 & 107 & 118 & 139 & 140 & 181 & 184 & 197 & 208 & 232 & 238 \\
DL, ppm & 38 & 20 & 6 & 6 & 10 & 3 & 2 & 2 & 0.8 & 6 & 5 & 4 & 1.5 & 0.8 \\
RSD, $\%$ & 50 & 17 & 13 & 23 & 25 & 21 & 17 & 14 & 16 & 18 & 50 & 20 & 17 & 21 \\
\hline
\end{tabular}

Note: DL-detection limit; RSD—relative standard deviation.

\section{Brief Geological Characteristics of the Pervomaiskoe Deposit}

The structure, mineralogical, and geochemical features as well as the origin of the mineralization of the Dzhidinskoe ore field have been studied by many researchers [1-4,18-28]. All the researchers marked the following feature of the Dzhidinskoe ore field: the hydrothermal ore formation had a pulsating character and repeatedly alternated with magmatic injections of mainly granite composition, and the ore mineralization profile changed in the following sequence: $\mathrm{Mo} \rightarrow \mathrm{Mo}+\mathrm{Be} \rightarrow \mathrm{Be}+\mathrm{W} \rightarrow \mathrm{W}+$ $\mathrm{Pb}, \mathrm{Zn}$.

The Pervomaiskoe molybdenum deposit forms the apical part of the granite stock with the same name. The deposit has already been mined as an open pit from 1941 to 1973 (Figure 1a). The Pervomaisky granite intrusion forms a laccolith with numerous apophyses in its apical part. Its area on the surface is $\sim 0.35 \mathrm{~km}^{2}$. Pervomaiskoe deposit is genetically related to the granite intrusive massif $[2,24,25]$. Ore-hosting granites have porphyritic structure and consist of potassium feldspar, quartz, plagioclase, and biotite with accessory apatite, secondary muscovite, rare pyrite, and fluorite. Porphyry phenocrysts are composed of quartz, potassium feldspar, and rare plagioclase.

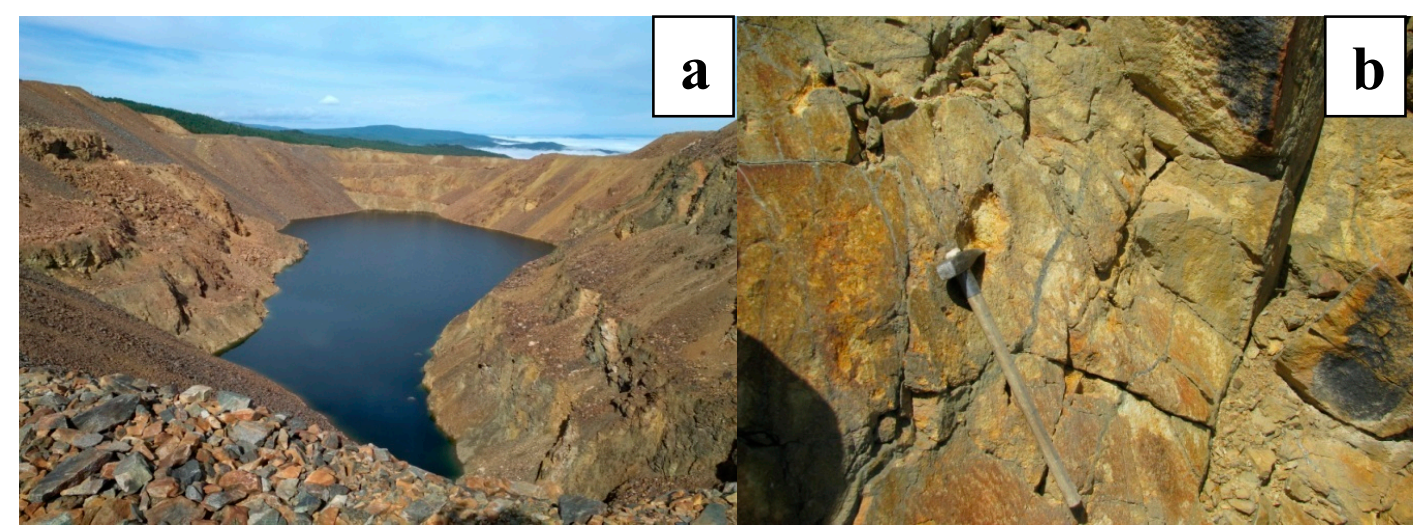

Figure 1. (a) Abandoned quarry at the Pervomaiskoe deposit; (b) quartz-molybdenite veinlets in the Pervomaisky stock granites. 
The deposit presents a stockwork of multioriented molybdenum-containing veinlets (Figure 1b). The size of the stockwork on the surface is $620 \times 540 \mathrm{~m}$; mineralization is traced to the depth of 240$250 \mathrm{~m}$ (Figure 2) [1]. The quartz-molybdenum stockwork of the Pervomaiskoe deposit is located both in the apical part of the massif (see Figure 2) and in the biotite-quartz hornfels. Wall-rocks are altered to muscovite-bearing greisens and the degree of greisenization decreases with depth. The highest-grade ores are composed of relatively thin quartz-molybdenite veinlets (up to $\sim 5 \mathrm{~cm}$ ), which are accompanied by disseminated molybdenite and molybdenite veinlets without quartz. Thick quartz veins (up to $1-1.5 \mathrm{~m}$ ) are rare. Average Mo content in the ores is $0.1-0.15 \mathrm{wt}$. \%.

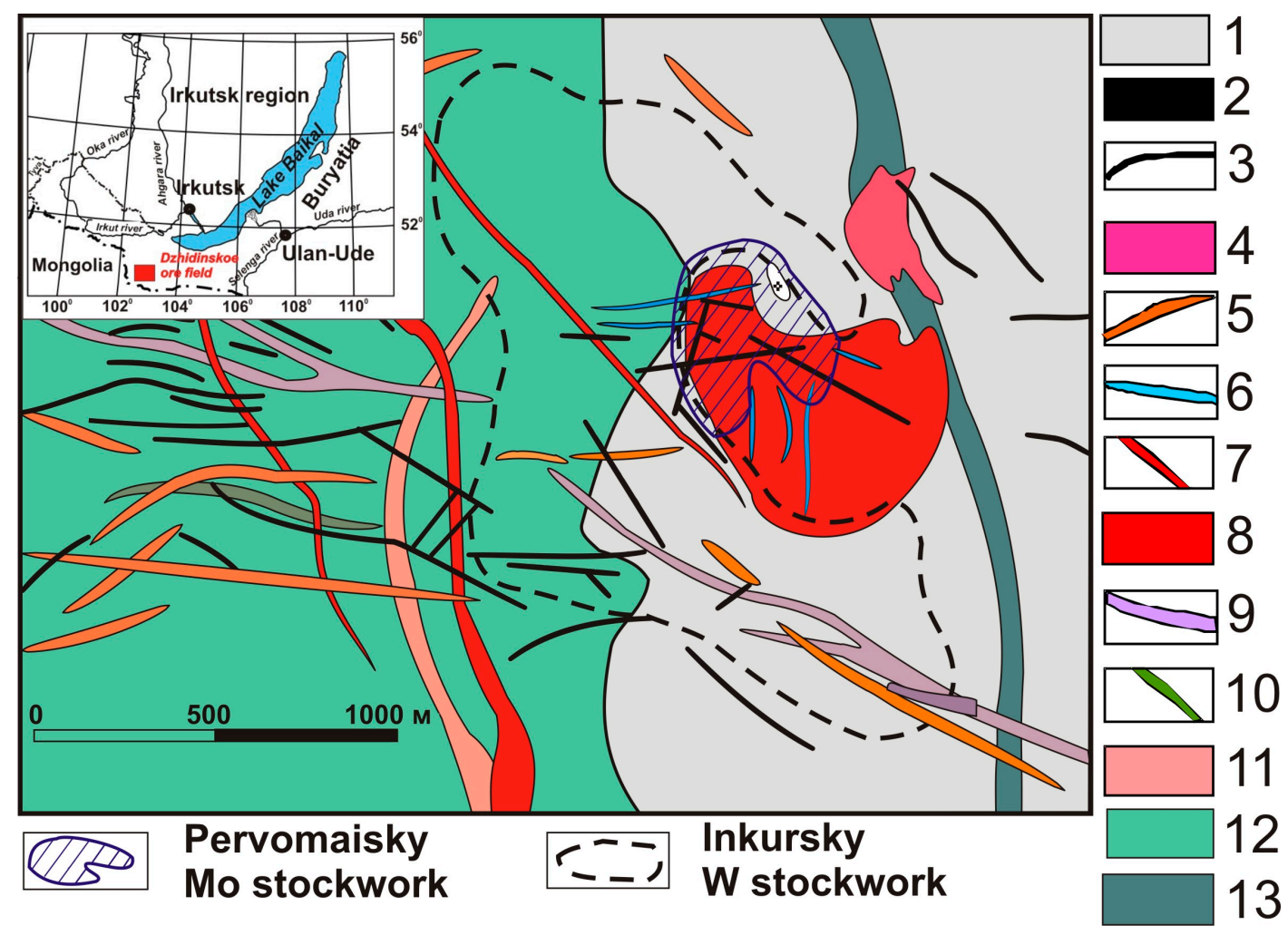

Figure 2. Schematic geological map of the Dzhidinskoe ore field (Ignatovich, 1975). 1-Khokhyurt set: effusives, 2-pyroclasts, shale; 3-quartz-sulfide-hubnerite veins; 4-Gorkinsky massif; 5-gray syenites; 6-quartz-molybdenum veins; 7-dykes of granite porphyry; 8-the Pervomaisky massif; 9-dikes of bostonites; 10-microdiorites; 11-plagiogranites; 12-diorites, quartz diorites; 13-peridotites, serpentinites.

\section{Isotopic Age of the Pervomaiskoe Deposit}

According to the results of the $\mathrm{Rb}-\mathrm{Sr}$ isochron dating, the formation age of the Pervomaisky granite stock is $124.3 \pm 1.6 \mathrm{Ma}$ [28].

$\mathrm{New} \mathrm{U}-\mathrm{Pb}$ dating of zircon has shown an age of $123.5 \pm 1.5 \mathrm{Ma}$ (Figure 3). The mean square of the weighted deviates (MSWD) is 0.99 . The average age based on the ${ }^{206} \mathrm{~Pb} /{ }^{238} \mathrm{U}$ ratio, corrected for the common lead by the ${ }^{207} \mathrm{~Pb}$-method is $123.4 \pm 1.4 \mathrm{Ma}$ (Figure 3 ). 

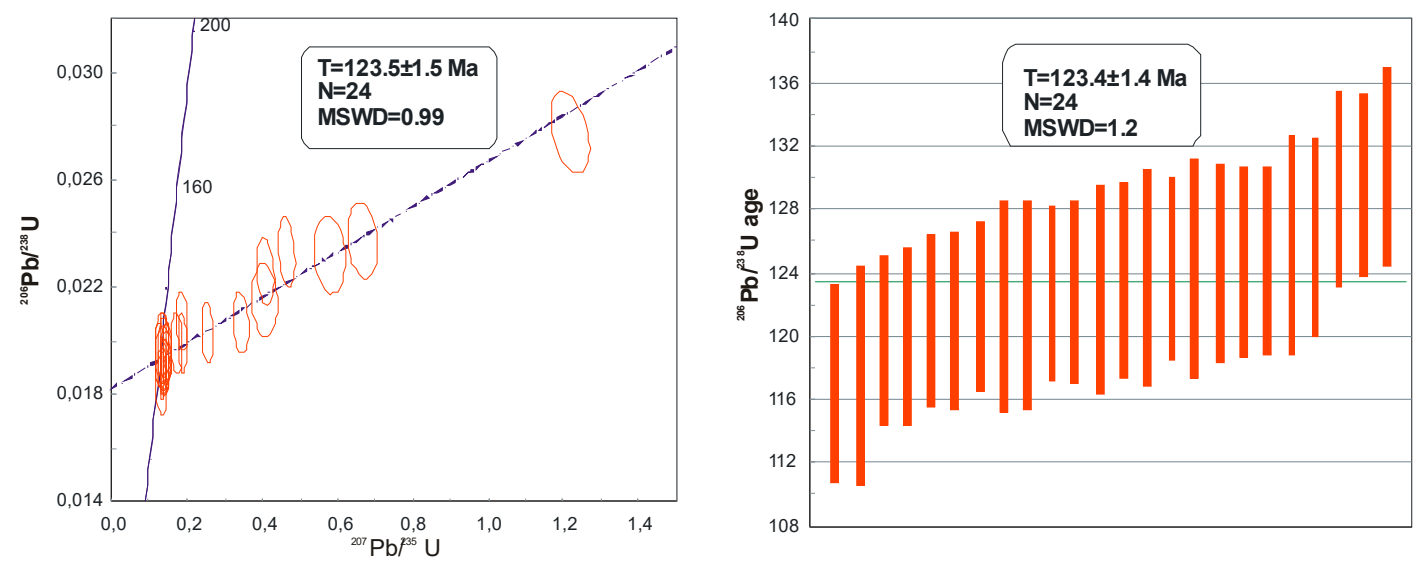

Figure 3. Concordia-Intercept age and average weighted ${ }^{206} \mathrm{~Pb} /{ }^{238} \mathrm{U}$ ages corrected for common lead by the ${ }^{207} \mathrm{~Pb}$-method for zircons from granites of the Pervomaisky massif.

${ }^{40} \mathrm{Ar} /{ }^{39} \mathrm{Ar}$ dating of muscovite from the quartz-molybdenite veinlets of the Pervomaiskoe deposit indicated the isotopic age of $127.6 \pm 1.5 \mathrm{Ma}$ (Figure 4).

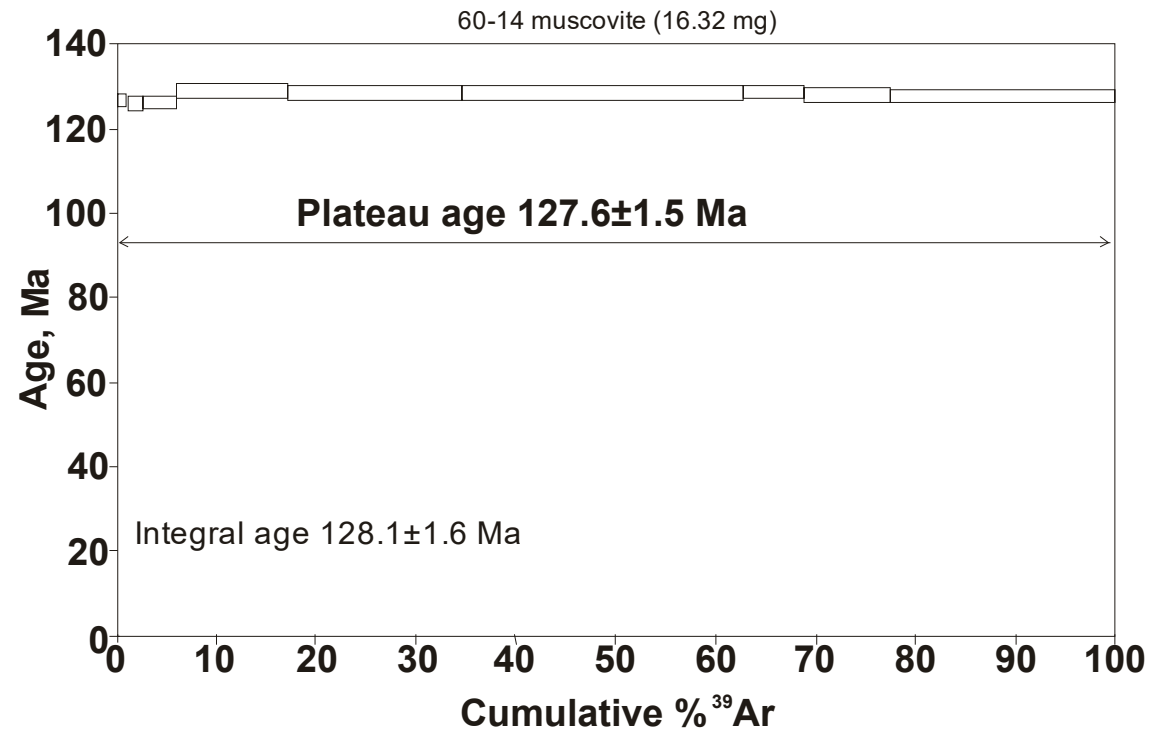

Figure 4. ${ }^{40} \mathrm{Ar} /{ }^{39} \mathrm{Ar}$ isotopic dating of muscovite from molybdenum ores of the Pervomaiskoe deposit.

Re-Os dating of molybdenite from the Pervomaiskoe deposit indicated two values of isotopic age: $118.5 \pm 1.6$ and $122.4 \pm 1 \mathrm{Ma}$ (Table 2).

Table 2. The isotopic age of molybdenite by ${ }^{187} \operatorname{Re}^{187}$ Os isotopic dating of molybdenite.

\begin{tabular}{|c|c|c|c|c|c|c|c|c|c|c|}
\hline & \multicolumn{2}{|c|}{ Common Os (ng/g) } & \multicolumn{2}{|c|}{${ }^{187} \operatorname{Re}(\mathrm{ng} / \mathrm{g})$} & \multicolumn{2}{|c|}{${ }^{187}$ Os (ng/g) } & \multicolumn{2}{|c|}{$\operatorname{Re}(\mathrm{ng} / \mathrm{g})$} & \multicolumn{2}{|c|}{ Model Age (Ma) } \\
\hline & & $1 \sigma$ & & $1 \sigma$ & & $1 \sigma$ & & $1 \sigma$ & & $1 \sigma$ \\
\hline Pm-18-1 & 0.088 & 0.007 & 10,790 & 391 & 22.03 & 0.28 & 17,237 & 624 & 122.4 & 1.6 \\
\hline Pm-18-2 & 0.082 & 0.009 & 9986 & 107 & 19.73 & 0.17 & 15,951 & 171 & 118.5 & 1.0 \\
\hline JDC-1 (standard) & 0.131 & 0.006 & 10,324 & 191 & 25.53 & 0.18 & 16,491 & 305 & 144.2 & 1.0 \\
\hline
\end{tabular}

\section{Structure and Composition of Ore Veinlets}

Molybdenum mineralization at the Pervomaiskoe deposit is mainly concentrated in quartz-molybdenite veinlets. Fluorite, K-feldspar, muscovite, beryl, and pyrite are found in the veinlets with different amounts. There are two types of veinlets: molybdenite-rich (type 1, Figure 5A-C) 
and molybdenite-poor veinlets (type 2, Figure 5D-F). The Mo content in molybdenite-quartz veinlets of the second type varies from 0.01 to $0.1 \mathrm{wt}$. \%, which is ten times lower than in the veinlets of the first type (up to $1-2$ wt. \%).

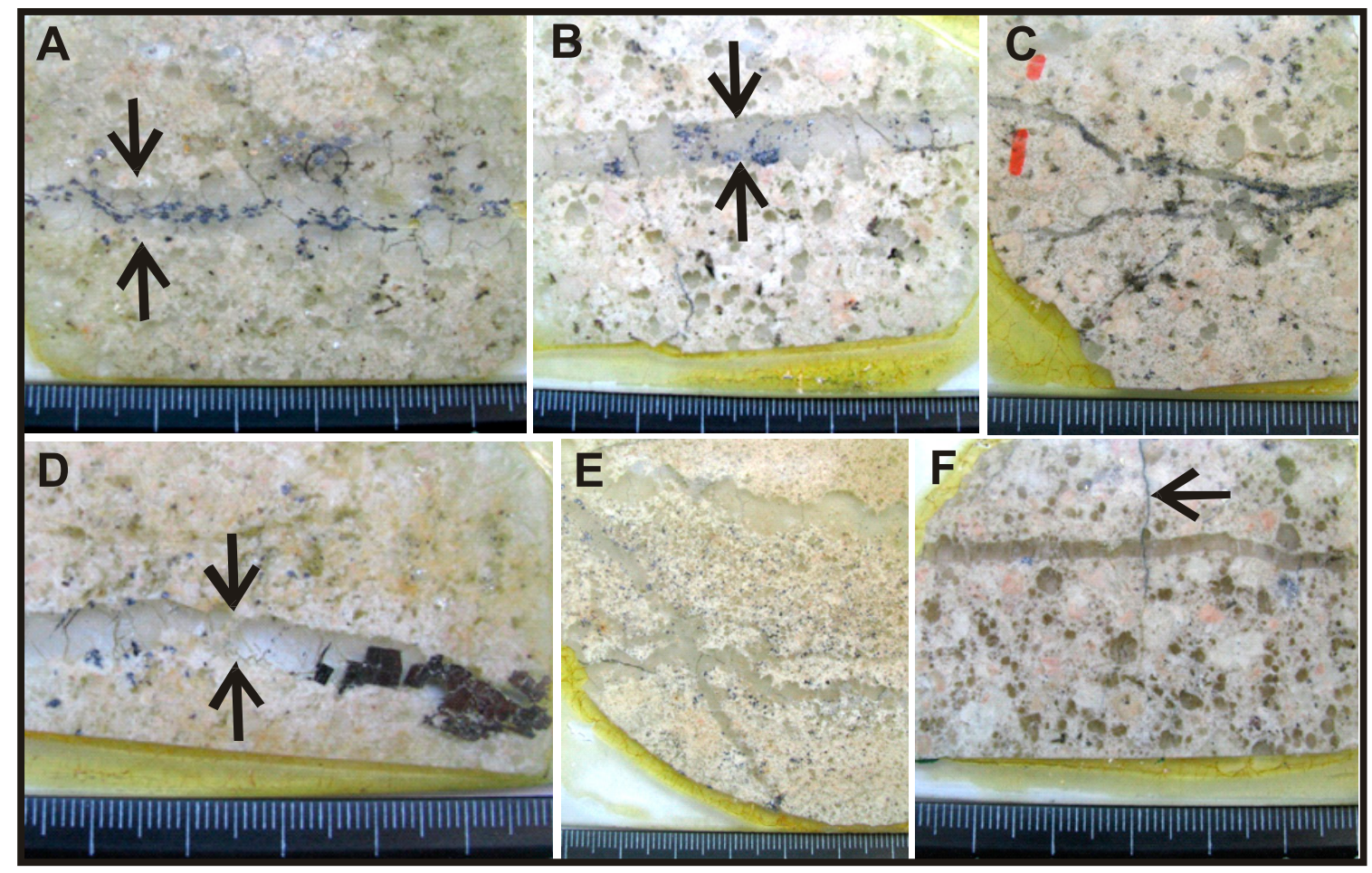

Figure 5. Quartz-molybdenite veinlets of type 1 (A-C) and molybdenite-poor veinlets of type 2 (D-F). The arrow in (F) indicates a narrow "dry" molybdenite veinlet. The arrows in other figures show the width of veins.

Molybdenite-quartz veinlets of both types are composed of 80-90\% isometric quartz grains, with some grains growing perpendicular to the walls of the veinlet. This indicates that the veinlets were most likely formed by filling cracks unlike metasomatic veinlets. The width of the veinlets mainly varies from 0.2 to $1.5 \mathrm{~cm}$, boundaries with host rocks are distinct, and in most cases, they are sharp, sometimes tortuous. Molybdenite forms clusters of flakes, sometimes radial aggregates; the amount of molybdenite is on the average $\sim 5-10 \%$. The distribution of molybdenite is uneven (Figure 4), in some cases it is confined to the central part (Figure 5A,B), in other cases it is confined to the selvages of veinlets (Figure 5C) or scattered throughout the whole vein quartz. In some areas molybdenite flakes extend beyond the veinlet boundaries into the host rocks (Figure 5E). "Dry" molybdenite veinlets often intersect quartz veinlets (Figure $5 \mathrm{~F}$, arrow).

In addition to quartz, the mineralogical and petrographic studies of the veinlet composition allow identification of the following vein minerals: muscovite, K-feldspar, albite, and fluorite (Figure 6, Table 3). 


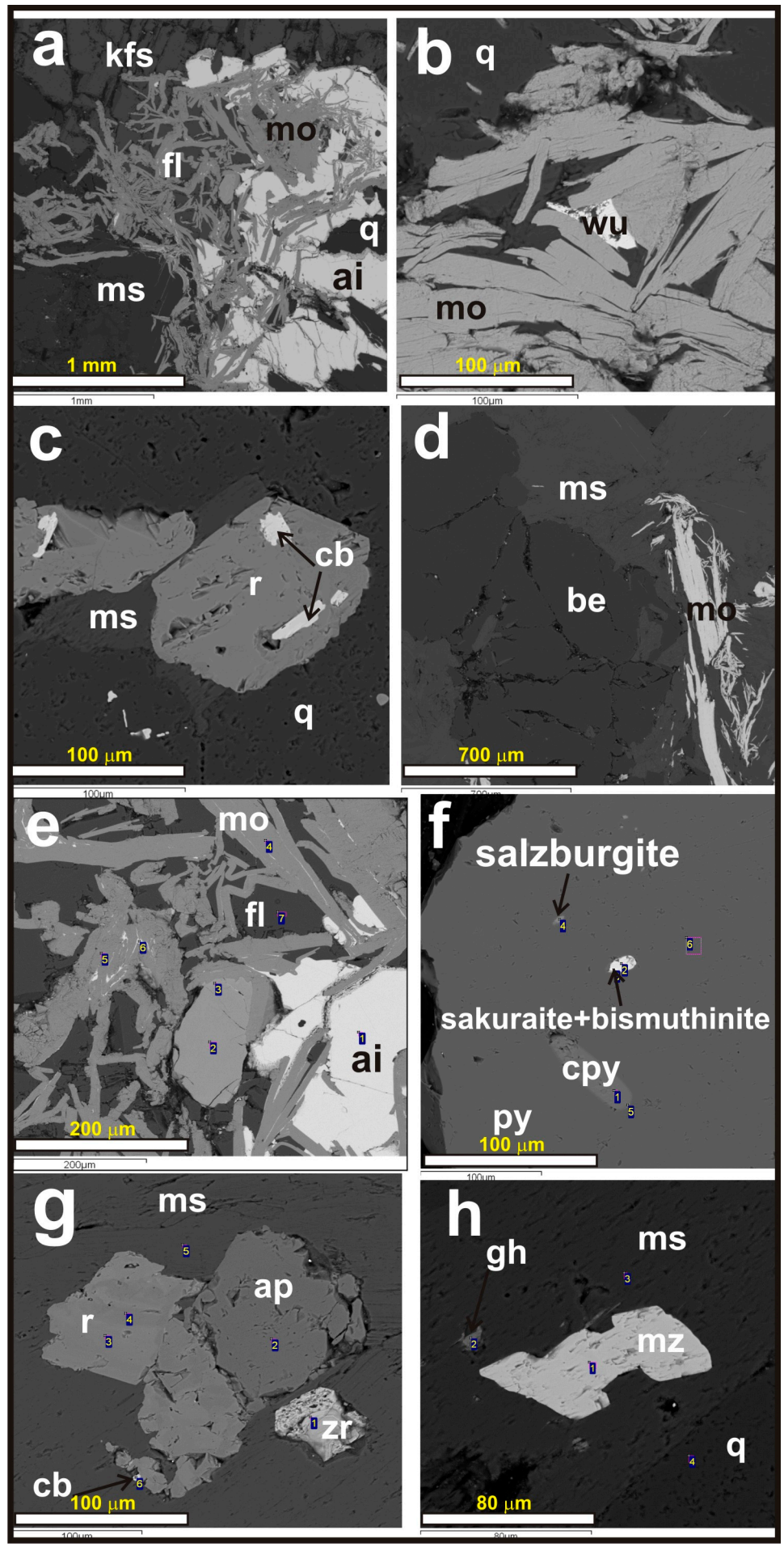

Figure 6. Ore minerals in quartz-molybdenite veinlets of the Pervomaiskoe deposit (photos in back-scattered electrons). (a) molybdenite aggregate in close intergrowth with aikinite; (b) wulfenite grain in the laminated aggregate of molybdenite; (c) inclusion of columbite in rutile; (d) beryl grains in contact with muscovite and molybdenite; (e) molybdenite with fluorite and aikinite; (f) microinclusions of rare sulfosalts and chalcopyrite in pyrite; (g) grains of rutile, apatite, zircon, and microinclusion of cubanite on contact with muscovite; (h) monazite and goethite grains; Abbreviations: mo-molybdenite; q-quartz; kfs-potassium feldspar; ms-muscovite; fl-fluorite; ai-aikinite; be-beryl; py—pyrite; cpy—chalcopyrite; ap—fluorapatite; cb—cubanite; $z r$-zircon; mz-monazite; gh—goethite. 
Table 3. Mineral composition of quartz-molybdenite veinlets.

\begin{tabular}{|c|c|c|}
\hline \multicolumn{2}{|c|}{ Association } & Mineral \\
\hline \multirow[b]{2}{*}{ Vein minerals } & Major & Quartz $\mathrm{SiO}_{2}$ \\
\hline & Minor & $\begin{array}{c}\text { Muscovite } \mathrm{KAl}_{2}\left(\mathrm{AlSi}_{3} \mathrm{O}_{10}\right)(\mathrm{OH})_{2} \\
\text { Potassium Feldspar }(\mathrm{Ca}, \mathrm{Na})(\mathrm{Al}, \mathrm{Si}) \mathrm{AlSi}_{2} \mathrm{O}_{8} \\
\text { Albite } \mathrm{Na}\left[\mathrm{AlSi}_{3} \mathrm{O}_{8}\right] \\
\text { Fluorite } \mathrm{CaF}_{2}\end{array}$ \\
\hline \multirow{3}{*}{ Ore minerals } & Major & $\begin{array}{c}\text { Molybdenite } \mathrm{MoS}_{2} \\
\text { Pyrite } \mathrm{FeS}_{2}\end{array}$ \\
\hline & Minor & $\begin{array}{c}\text { Galena PbS, sphalerite } \mathrm{ZnS} \\
\text { Chalcopyrite } \mathrm{CuFeS}_{2} \\
\text { Beryl } \mathrm{Al}_{2} \mathrm{Be}_{3}\left[\mathrm{Si}_{6} \mathrm{O}_{18}\right] \\
\text { Columbite }(\mathrm{Fe}, \mathrm{Mn} \pm \mathrm{W}, \mathrm{Sc})(\mathrm{Nb}, \mathrm{Ta} \pm \mathrm{Ti})_{2} \mathrm{O}_{6} \\
\text { Aikinite } \mathrm{PbCuBiS} \\
\text { Wulfenite } \mathrm{Pb}\left(\mathrm{MoO}_{4}\right) \\
\text { Bismutinite } \mathrm{Bi}_{2} \mathrm{~S}_{3}\end{array}$ \\
\hline & Rare & $\begin{array}{c}\text { Uraninite }\left(\mathrm{UO}_{2}\right) \\
\text { Sakuraite }(\mathrm{Cu}, \mathrm{Zn}, \mathrm{Fe})_{3}(\mathrm{In}, \mathrm{Sn}) \mathrm{S}_{4} \\
\text { Salzburgite } \mathrm{Pb}_{1.6} \mathrm{Cu}_{1.6} \mathrm{Bi}_{6.4} \mathrm{~S}_{12}\end{array}$ \\
\hline \multicolumn{2}{|c|}{ Accessory minerals } & $\begin{array}{c}\text { Rutile } \mathrm{TiO}_{2} \\
\text { Monazite }(\mathrm{Ce}, \mathrm{La}, \mathrm{Nd}, \mathrm{Th})\left[\mathrm{PO}_{4}\right] \\
\text { Fluorapatite } \mathrm{Ca}_{5}\left[\mathrm{PO}_{4}\right]_{3} \mathrm{~F} \\
\text { Zircon } \mathrm{ZrSiO}_{4}\end{array}$ \\
\hline \multicolumn{2}{|c|}{ Secondary minerals } & $\begin{array}{c}\text { Anglesite } \mathrm{PbSO}_{4} \\
\text { Goethite } \mathrm{FeO}(\mathrm{OH})\end{array}$ \\
\hline
\end{tabular}

Molybdenite is most abundant among the ore minerals; pyrite and aikinite are present in relatively smaller quantities. A large number of mineral phases were found, including sulfides (pyrite, galena, sphalerite, chalcopyrite, bismuthinite), as well as columbite, wulfenite, beryl, and sulfosalts (sacuraite, salzburgite) (Figure 6). Rare grains of rutile, monazite, fluorapatite, and zircon occur as the accessory minerals, while anglesite and goethite form secondary (supergenic) phases.

The changes in the composition of the host granites is fixed in narrow $(1-3 \mathrm{~cm})$ zones adjacent to the ore veinlets, which indicates the diffusion-metasomatic nature of these rims. Among the main oxides, only $\mathrm{TiO}_{2}, \mathrm{FeO}, \mathrm{MnO}$, and $\mathrm{MgO}$ do not exhibit significant deviations from the background values characteristic of unaltered granites. Different types of molybdenite-quartz veinlets also vary noticeably by the behavior of some elements in the near-veinlet rims. Molybdenite-poor veinlets (type 2) are accompanied by rims that are sharply depleted of $\mathrm{SiO}_{2}$ and $\mathrm{Na}_{2} \mathrm{O}$, enriched in $\mathrm{K}_{2} \mathrm{O}$, sometimes $\mathrm{Al}_{2} \mathrm{O}_{3}, \mathrm{Fe}_{2} \mathrm{O}_{3}$, and $\mathrm{S}$, with a low $\mathrm{F}$ content. Metasomatites of wall-rocks in poor veins are usually enriched in $\mathrm{Mo}, \mathrm{W}, \mathrm{Sn}$, and $\mathrm{Li}$ and are poor in $\mathrm{Zn}$.

Desilication of granites and increase of $\mathrm{K}_{2} \mathrm{O}$ in the near-veinlet rims are not characteristic of high-grade veinlets (type 1), and their depletion of $\mathrm{Na}_{2} \mathrm{O}$ and $\mathrm{Al}_{2} \mathrm{O}_{3}$ is observed in cases of increased fluorite content in the vein material. Near-veinlet rims of this type are characterized by enrichment in $\mathrm{F}$ and $\mathrm{S}$. With relatively low concentrations of $\mathrm{Mo}$ and $\mathrm{Sn}$, changes in the $\mathrm{Pb}$ content are alternating (Figure 7). 

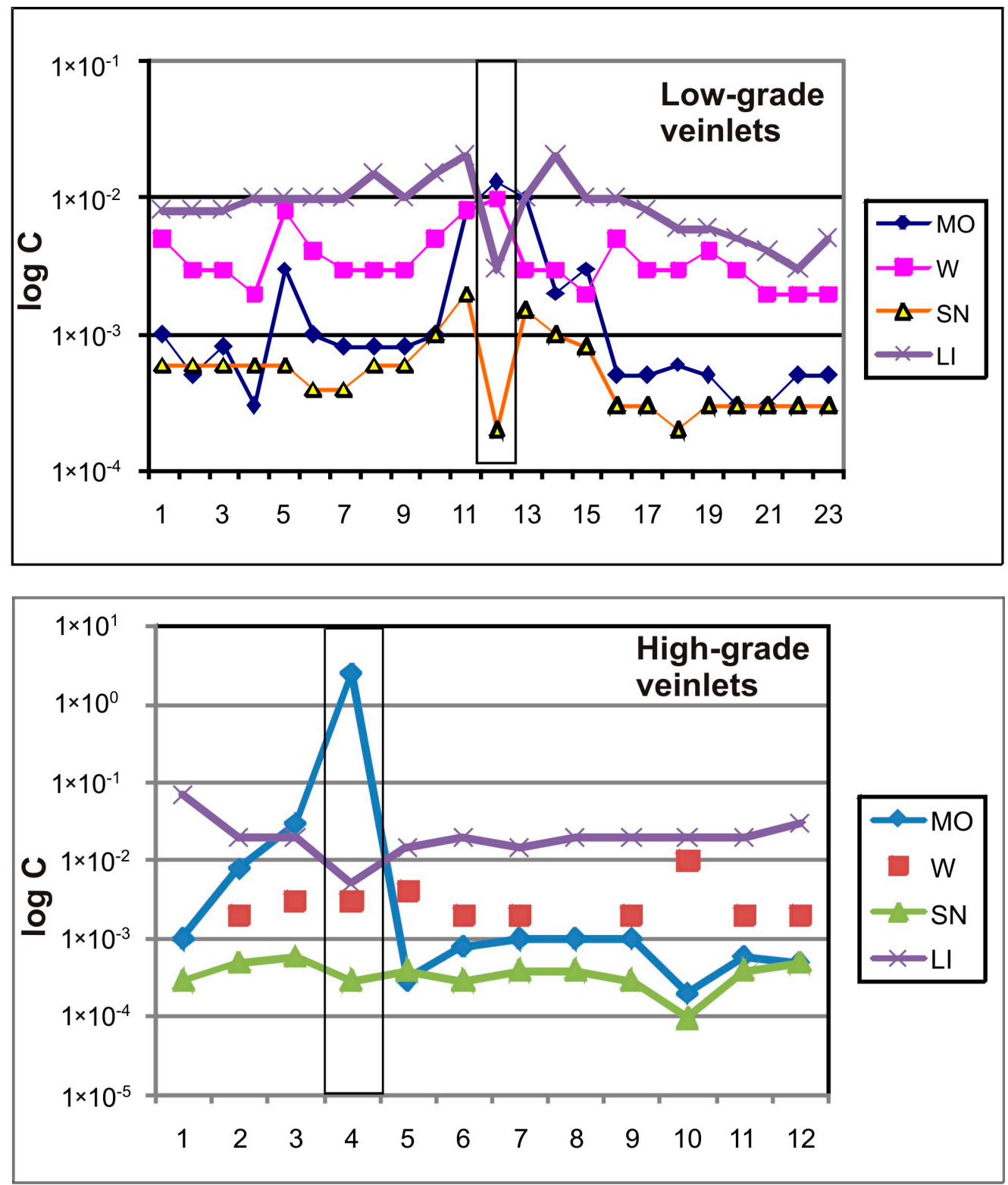

Figure 7. Distribution of some elements near the quartz-molybdenite veinlets (rectangles) of two types. The horizontal axis shows the sample numbers; C-concentrations in wt. \%.

\section{Fluid Inclusion Study}

Primary relatively large fluid inclusions (FIs) with size up to $\sim 15-20 \mu \mathrm{m}$ were studied in quartz grains, far from the healed cracks and trains of secondary inclusions. These FIs were found in different veinlets but are the same type (Figure 8) and belong to the two-phase (gas + liquid) inclusions. Usually, such FIs are characterized by the absence of solid phases and the presence of a gas bubble that does not have visible edging of liquid $\mathrm{CO}_{2}$. 


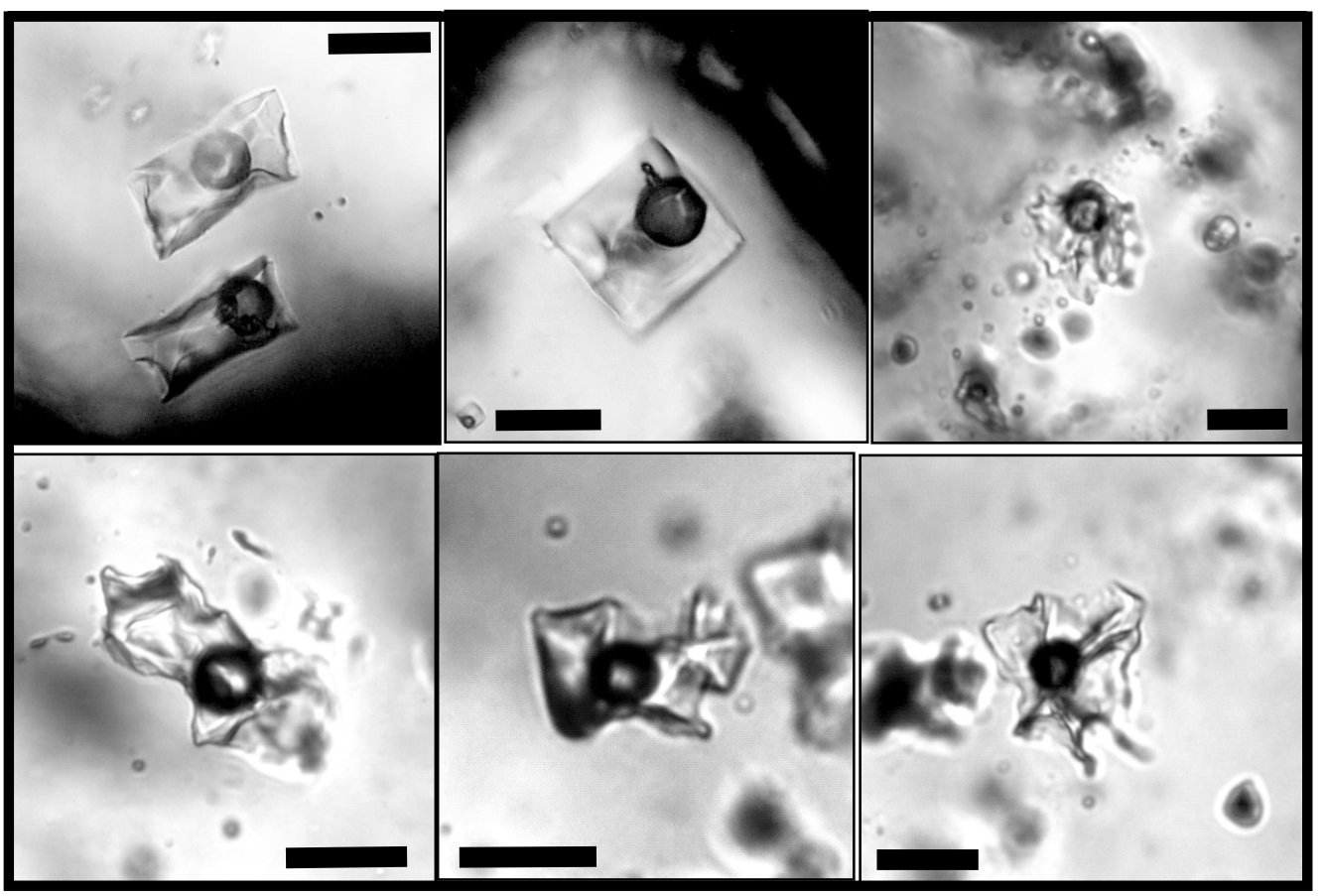

Figure 8. Primary fluid inclusions of homogeneous capture in quartz from quartz-molybdenite veinlets of the Pervomaiskoe deposit. The length of the scalebar-10 microns.

Groups of very small aqueous- and gas-dominated FIs were also found in a few quartz grains (Figure 9). Such inclusions are located within the same growth zone, which indicates their syngenesis. They have very small dimensions $(\leq 2-5 \mu \mathrm{m}$ ) and in isolated cases reach $\sim 7-9 \mu \mathrm{m}$ (Figure $9 \mathrm{a}, \mathrm{b}$ ) which made it difficult to conduct thermometric experiments. Nevertheless, the presence of such inclusions may indicate periods of heterogenization (boiling up) of the ore-forming solution [29].

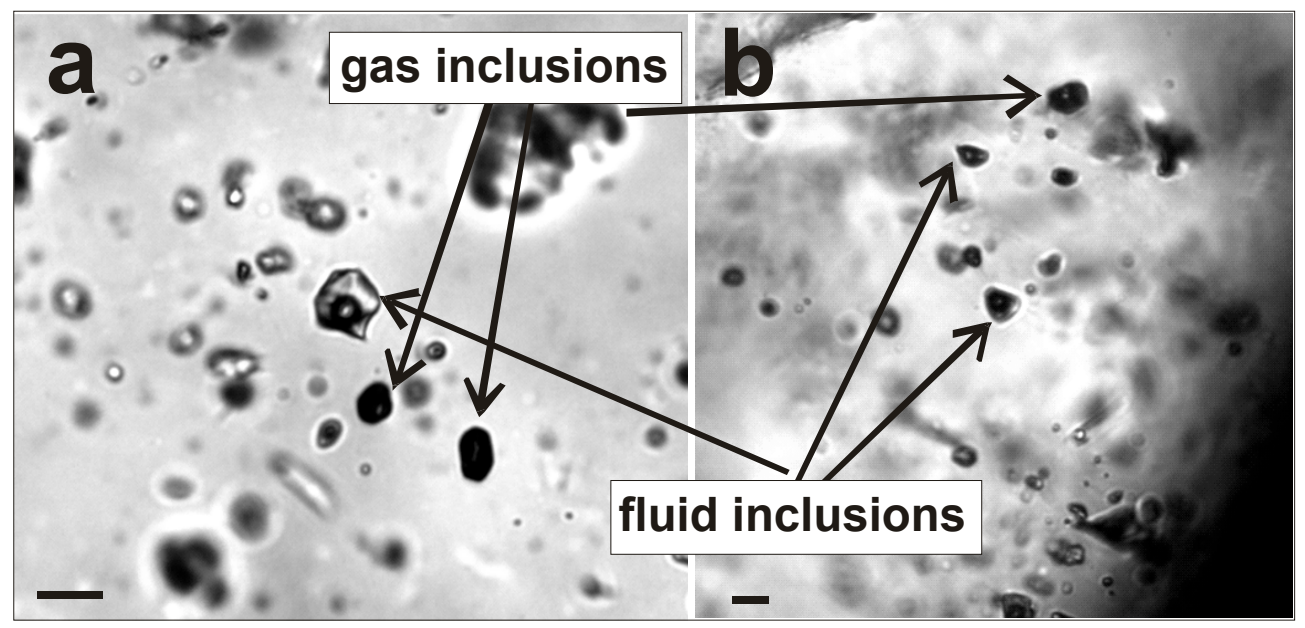

Figure 9. Rare primary aqueous-dominated and gas-dominated fluid inclusions of heterogeneous capture in quartz from high-grade quartz-molybdenite veinlets (a) and molybdenite-poor veinlets (b) of the Pervomaiskoe deposit. The length of the scalebar-10 microns.

The results of thermometric and cryometric studies of fluid inclusions from different types of veinlets are summarized in Table 4. 
Table 4. Results of the FI study in quartz from the ore veinlets of the Pervomaiskoe deposit.

\begin{tabular}{|c|c|c|c|c|c|c|}
\hline Host Mineral & $T_{\mathrm{g}}$ & $\begin{array}{c}T_{\mathrm{pl} \mathrm{ice}} \\
{ }^{\circ} \mathrm{C}\end{array}$ & $T_{\text {eut }}$ & $\begin{array}{c}\text { Salinity } \mathrm{NaCl} \\
\text { Equivalent (wt. \%) } \\
{[30]}\end{array}$ & $\begin{array}{c}\text { Total } \\
\text { Density }\end{array}$ & $\begin{array}{c}\text { Type of Salt System } \\
{[16]}\end{array}$ \\
\hline $\begin{array}{l}\text { Quartz (high-grade } \\
\text { Q-Mo veinlets) }\end{array}$ & $\begin{array}{l}\geq+314 \\
+216\end{array}$ & $-8.9-3.9$ & $\begin{array}{l}-49.8-55 \\
-37-38\end{array}$ & [30] & $0.85-0.94$ & $\begin{array}{c}\mathrm{CaCl}_{2}-\mathrm{H}_{2} \mathrm{O} \\
\mathrm{CaCl}_{2}-\mathrm{NaCl}_{-} \mathrm{H}_{2} \mathrm{O} \\
\mathrm{CaCl}_{2}-\mathrm{MgCl}_{2}-\mathrm{H}_{2} \mathrm{O} \\
\mathrm{CaCl}_{2}-\mathrm{KCl}^{-} \mathrm{H}_{2} \mathrm{O} \\
\mathrm{NaCl}^{-}-\mathrm{FeCl}_{2}-\mathrm{H}_{2} \mathrm{O} \\
\mathrm{MgCl}_{2}-\mathrm{KCl}_{-} \mathrm{H}_{2} \mathrm{O} \\
\mathrm{FeCl}_{3}-\mathrm{H}_{2} \mathrm{O}\end{array}$ \\
\hline $\begin{array}{l}\text { Quartz (low-grade } \\
\text { Q-Mo veinlets) }\end{array}$ & $\begin{array}{l}\geq+312 \\
+186\end{array}$ & $-6-4$ & $\begin{array}{l}-49.5-53.5 \\
-36.1-39\end{array}$ & $6.5-9.2$ & $0.89-0.94$ & $\begin{array}{c}\mathrm{CaCl}_{2}-\mathrm{H}_{2} \mathrm{O} \\
\mathrm{CaCl}_{2}-\mathrm{NaCl}^{-} \mathrm{H}_{2} \mathrm{O} \\
\mathrm{CaCl}_{2}-\mathrm{MgCl}_{2}-\mathrm{H}_{2} \mathrm{O} \\
\mathrm{CaCl}_{2}-\mathrm{KCl}^{-} \mathrm{H}_{2} \mathrm{O} \\
\mathrm{NaCl}-\mathrm{FeCl}_{2}-\mathrm{H}_{2} \mathrm{O} \\
\mathrm{MgCl}_{2}-\mathrm{KCl}_{2} \mathrm{O} \\
\mathrm{FeCl}_{3}-\mathrm{H}_{2} \mathrm{O}\end{array}$ \\
\hline $\begin{array}{c}\text { Quartz (Reyf, } \\
\text { Bazheev, 1982; } \\
\text { Stelmachonok, 1995) }\end{array}$ & $\begin{array}{l}\geq+250 \\
+210\end{array}$ & $-9.2-4.3$ & $-27-31$ & & & \\
\hline
\end{tabular}

Note: $T_{g}$ is homogenization temperature, $T_{p l i c e}$ is ice melting temperature, $T_{e u t}$ is eutectic temperature.

The homogenization temperature ranges for the studied primary fluid inclusions in the quartz of Mo-rich $\left(\geq 314-216^{\circ} \mathrm{C}\right)$ and Mo-poor $\left(\geq 312-186^{\circ} \mathrm{C}\right)$ veinlets are close. According to Reyf, Bazheev [24], and Stelmachonok [26,27], homogenization temperatures of most primary fluid inclusions in the veinlets vary within a narrow range of lower temperatures of $\sim 250-210^{\circ} \mathrm{C}$. Eutectic temperatures vary from -36.1 to $-39^{\circ} \mathrm{C}$ and from -49.5 to $-55^{\circ} \mathrm{C}$, which most closely corresponds to the systems $\mathrm{CaCl}_{2}-\mathrm{H}_{2} \mathrm{O}, \mathrm{CaCl}_{2}-\mathrm{NaCl}-\mathrm{H}_{2} \mathrm{O}, \mathrm{CaCl}_{2}-\mathrm{MgCl}_{2}-\mathrm{H}_{2} \mathrm{O}, \mathrm{CaCl}_{2}-\mathrm{KCl}-\mathrm{H}_{2} \mathrm{O}, \mathrm{MgCl}_{2}-\mathrm{H}_{2} \mathrm{O}, \mathrm{MgCl}_{2}-\mathrm{NaCl}_{2}-\mathrm{H}_{2} \mathrm{O}$, and $\mathrm{FeCl}_{2}-\mathrm{H}_{2} \mathrm{O}$ [16].

Ice melting temperatures for Mo-rich veinlets vary from -3.9 to $-8.9^{\circ} \mathrm{C}$, which corresponds to the total salinity of 6.3 to $12.7 \mathrm{wt}$. \% eq. $\mathrm{NaCl}$. The temperatures of Mo-poor veinlets are slightly lower $(-6$ to $-4{ }^{\circ} \mathrm{C}$ ), which correspond to the salinity of 6.5 to $9.2 \mathrm{wt}$. \% eq. $\mathrm{NaCl}$. Raman spectroscopy identified $\mathrm{CO}_{2}, \mathrm{CH}_{4}$ within the gas phase of individual inclusions from both types of quartz-molybdenum veinlets, and a very weak $\mathrm{N}_{2}$ peak in some FIs (Figure 10).
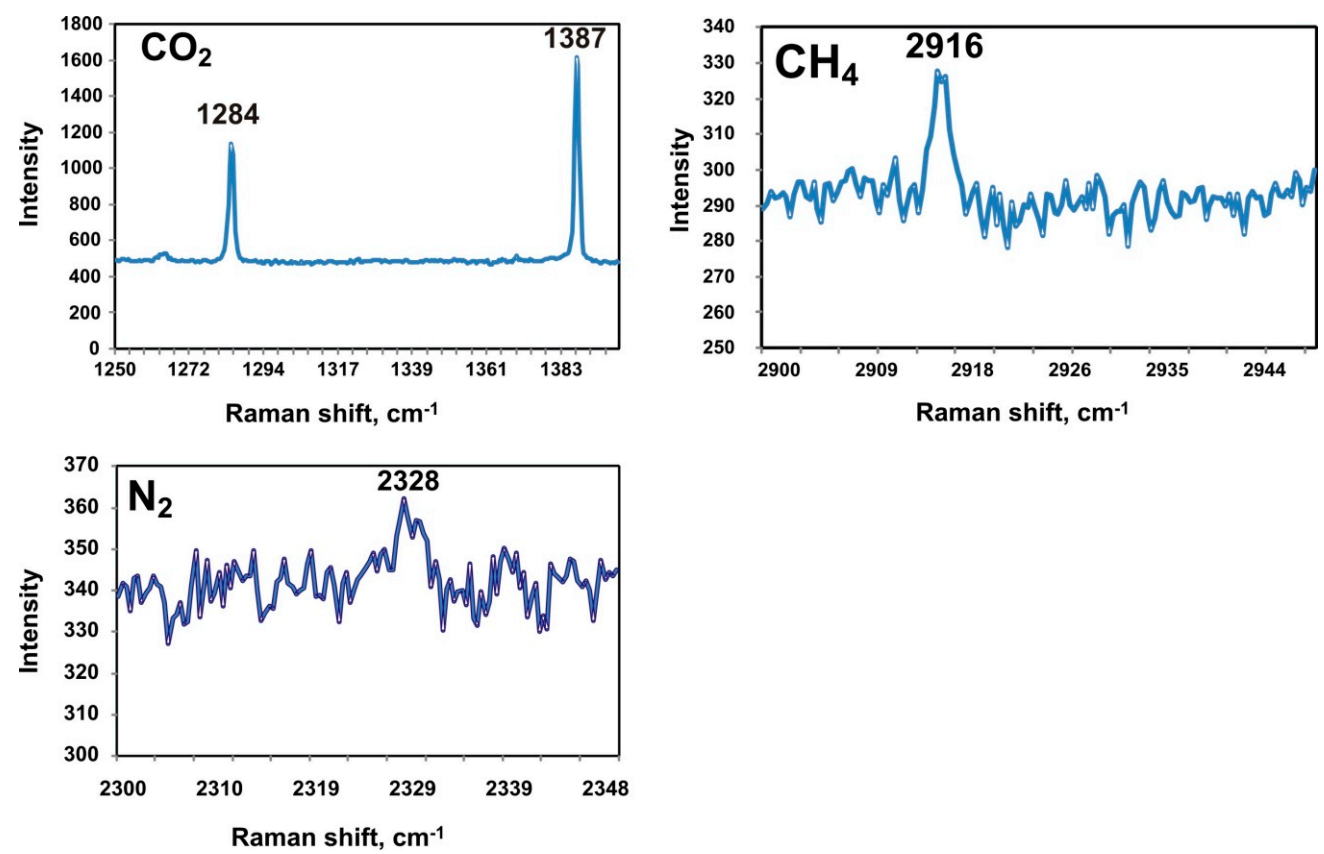

Figure 10. Results of Raman spectroscopy of individual primary fluid inclusions. 


\section{Metal Content of Solutions}

Using the LA-ICP-MS method, the concentrations of a series of elements, $\mathrm{Li}, \mathrm{Be}, \mathrm{B}, \mathrm{F}, \mathrm{Na}, \mathrm{Mg}, \mathrm{Al}$, $\mathrm{Cl}, \mathrm{K}, \mathrm{Ca}, \mathrm{Mn}, \mathrm{Fe}, \mathrm{Cu}, \mathrm{Zn}, \mathrm{Nb}, \mathrm{Mo}, \mathrm{Ag}, \mathrm{Sn}, \mathrm{La}, \mathrm{Ce}, \mathrm{Ta}, \mathrm{W}, \mathrm{Au}, \mathrm{Pb}, \mathrm{Th}, \mathrm{U}$, were determined in individual FIs (Table 5).

Table 5. Metal content in ore-forming solutions of the Pervomaiskoe deposit.

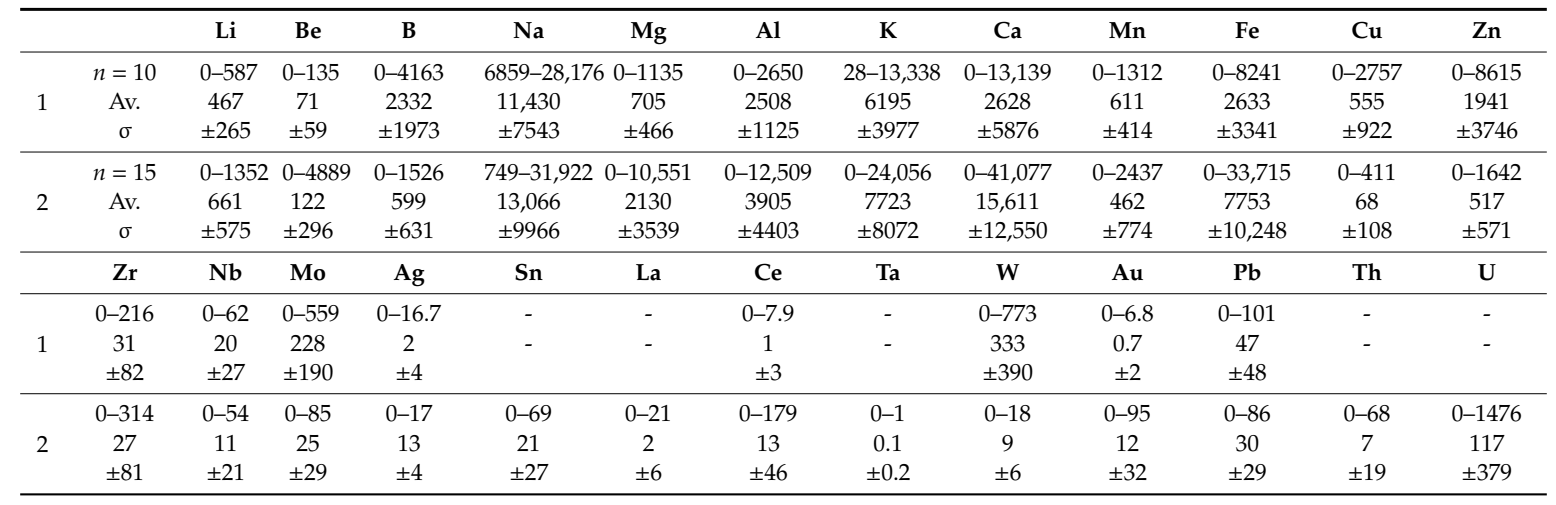

Note: 1-high-grade quartz-molybdenite veinlets, 2-low-grade quartz-molybdenite veinlets. An empty graph — below the detection limit; $n$-number of analyzes. Top line—value scatter, Av-—average value, $\sigma$-standard deviation, dash-element not determined.

Fluid inclusions in quartz from quartz-molybdenite veins contain $\mathrm{Na}, \mathrm{K}, \mathrm{Ca}$, and $\mathrm{Fe}$ as the main components with minor $\mathrm{Li}, \mathrm{Mg}$, and $\mathrm{Mn}$, which correlates with cryometry data. The main ore elements in high-grade veinlets are $\mathrm{Mo}, \mathrm{Cu}, \mathrm{Zn}, \mathrm{W}, \mathrm{Be}$, whereas $\mathrm{Nb}, \mathrm{Zr}$, and $\mathrm{Pb}$ are present in lower concentrations. FIs from low-grade veinlets are distinguished by low concentrations of the most of ore element, except REE.

The Mo content in high-grade veinlets reaches $559 \mathrm{ppm}$ with an average of $228 \mathrm{ppm}$, whereas in low-grade veinlets, it does not exceed $85 \mathrm{ppm}$, with an average of $25 \mathrm{ppm}$.

\section{Discussion}

The Pervomaiskoe deposit is an ore stockwork localized directly in granites. The geochronological studies indicate genetic relationship of mineralization with the parent pluton. The study of ore veinlets allowed identifying formation conditions of molybdenum mineralization and the composition of ore-forming solutions.

Among the ore veinlets, relatively rich (type 1 ) and relatively poor (type 2 ) veinlets are distinguished in terms of the molybdenite content. The analysis of fluid inclusions shows that these veinlets differ in concentrations of most ore-forming components, including $\mathrm{Mo}, \mathrm{W}, \mathrm{Cu}$, and $\mathrm{Zn}$. These types of veinlets also differ in the chemistry of the near-veinlet rims. Because the veinlets are localized in homogeneous porphyry granites, the differences in the composition of veinlets and differences in geochemical characteristics of the near-vein metasomatic rims can be explained only by differences in the composition of ore-forming solutions.

The rims of the first type veinlets are characterized by relatively high concentration of $\mathrm{F}, \mathrm{S}$, and $\mathrm{Si}$, while the rims of the second type are rich in $\mathrm{K}, \mathrm{Li}, \mathrm{Sn}, \mathrm{W}$, and Mo, but poor in $\mathrm{Si}$ and $\mathrm{Al}$. Based on the chemical composition of the near-veinlet metasomatic rims, it can be concluded that Mo-rich veinlets were formed by near-neutral solutions with a high content of Mo, S, and F, while relatively Mo-poor veinlets were deposited from more alkaline solutions.

This conclusion is consistent with the data provided by Kolonin [31] who demonstrated that low concentrations of molybdenum $(\sim 10-5 \mathrm{~mol} / \mathrm{kg}$ or $\sim 0.001 \mathrm{~g} / \mathrm{kg})$ can be found in neutral and moderately acidic conditions in equilibrium with molybdenite, and at $\mathrm{pH} \geq 8$, Mo concentrations increase vastly (by approximately 1-2 orders). The reason for the deposition of molybdenite in this case may be the neutralization and further acidification of the solutions that initially had an alkaline composition. 
This is consistent with our data indicating a higher content of molybdenite in the veinlets formed by near-neutral solutions (the first type) compared to the veinlets of the second type which were formed under relatively alkaline conditions. With increasing alkalinity of solutions, the reverse process of molybdenite dissolution is also possible. Consequently, the $\mathrm{pH}$ of solutions is one of the main factors of the ore productivity. Neutralization of ore-forming solutions transporting molybdenum and related components is probably due to the mixing of magmatic alkaline solutions and meteoric waters. This is confirmed by oxygen isotopes of vein minerals from the Pervomaiskoe Mo deposit $\left(\delta^{18} \mathrm{O}=\right.$ $3.8-6.6 \%$ ) [32].

The main ore mineral of the studied deposit is molybdenite. However, besides molybdenite, there are many other ore minerals, of which about 20 mineral species were identified (Table 2). Based on the chemical composition of ore and vein minerals, it is possible to qualitatively estimate the elemental composition of ore-forming solutions. The main vein minerals are quartz, potassium feldspar, fluorite, muscovite, albite, which indicates the presence of such elements as $\mathrm{Na}, \mathrm{K}, \mathrm{Al}, \mathrm{Si}$, and $\mathrm{F}$ in the composition of ore-forming fluids. The ore mineral association of molybdenite, other sulfides, and sulfosalts indicates the presence of $\mathrm{Mo}, \mathrm{S}, \mathrm{Fe}, \mathrm{Cu}, \mathrm{Pb}, \mathrm{Zn}$, and $\mathrm{Bi}$, and small amounts of $\mathrm{In}$ and $\mathrm{Sn}$ in the ore-forming solutions. In addition, minerals such as beryl, columbite, monazite, uraninite, zircon, apatite, and rutile are present in the ore veinlets. Accordingly, the solutions also contained $\mathrm{Be}, \mathrm{Nb}$, $\mathrm{Ta}, \mathrm{Ti}, \mathrm{REE}, \mathrm{Ca}, \mathrm{Zr}$, and $\mathrm{P}$ with an admixture of $\mathrm{Cl}, \mathrm{Mn}, \mathrm{W}$, and Sc. These results indicate a significant amount of ore elements in the ore-forming hydrothermal fluids.

The relative enrichment of molybdenite in the ore mineral association may be either due to a high Mo content relative to other elements in solutions, or to specific physical and chemical parameters that are specifically favorable for the deposition of molybdenite compared to other minerals, with similar concentrations of different ore-forming elements in the primary solution. The average Mo content in individual FIs is $\sim 228 \mathrm{ppm}$ with a maximum value of $\sim 582 \mathrm{ppm}$. Determined Mo contents are comparable (or less) with the concentrations of other ore elements, such as $\mathrm{Cu}$ and $\mathrm{Zn}$. However, molybdenite is the more common mineral in the veinlets compared with other metal-bearing minerals. It testifies favorable conditions for the deposition of molybdenum rather than other components of the solution.

The homogenization temperatures of the FIs as well as the total salinity of the ore-forming fluids in the veinlets of different types are identical. Thus, the values of total salinity for inclusions from both types of veinlets vary within the same range of $\sim 6.3$ to $12.7 \mathrm{wt}$. \% eq. $\mathrm{NaCl}$, the homogenization temperatures of FIs are also close and are in the range of $\sim 186$ to $314^{\circ} \mathrm{C}$. The maximum of the values falls on the interval of $250-300{ }^{\circ} \mathrm{C}$, corresponding to the modal value of this parameter for Mo deposits of this type in general [33]. The calculation of temperature by using the isotope geothermometer carried out according to the data published in the article [34], using the pair of quartz-K-feldspar based on equations [34,35], showed a value of $301^{\circ} \mathrm{C}$. Consequently, the temperatures of formation of vein minerals correspond to the maximum measured values of homogenization temperatures $\left(300-314^{\circ} \mathrm{C}\right)$. Taking into account the spread in values of homogenization temperatures of FIs, it is possible to accept an interval of $\sim 250-300{ }^{\circ} \mathrm{C}$ as the most likely interval of ore deposition temperatures.

The results of cryometric studies of FIs indicated eutectic temperatures of $\mathrm{Ca}, \mathrm{Na}, \mathrm{K}, \mathrm{Fe}$, and Mg. LA-ICP-MS results show that $\mathrm{Na}$ is the main cation, whereas $\mathrm{Ca}, \mathrm{K}$, and Fe are present in smaller amounts. The total salt composition of the solutions is almost identical in FIs from veinlets of the first and second types, despite some differences in the concentrations of the main elements. Consequently, ores were deposited from aqueous solutions containing chlorides of $\mathrm{Na}, \mathrm{Ca}, \mathrm{Fe}$, and $\mathrm{K}$, while chlorides of $\mathrm{Mg}$ are present in insignificant concentrations. Raman spectroscopy of individual inclusions made it possible to establish that $\mathrm{CO}_{2}$ is dominant in the gas phase of the ore-forming fluid, and methane is also present. The appearance of methane may be due to the presence of a mantle fluid influence. The presence of deep substance in ores is also confirmed by the sulfur isotope studies of the molybdenite [32]. 
The obtained age estimates of zircons ( $124 \pm 2 \mathrm{Ma})$ from granites, muscovite (127.6 $\pm 1.5 \mathrm{Ma})$, and molybdenite $(118.5 \pm 1.6$ and $122.4 \pm 1 \mathrm{Ma})$ from the ore zones of the Pervomaisky pluton are consistent with each other within the errors of the methods used. These data indicate the genetic relationship of mineralization with the formation of host granites. It should also be noted that such dates are known in relation to the magmatic series of Transbaikalia and Mongolia. Thus, according to [36], in the Middle and Late Mesozoic the territory of Western Transbaikalia was involved in the processes of tectonic-magmatic activation of the Central Asian orogenic belt, during which the system of interplate rift troughs with the eruption of platobasalts and the emplacement of rare-metal ore-bearing granites occurred.

\section{Conclusions}

(1). The Pervomaisky massif is one of the most representative examples of the ore-bearing granites of the Late Mesozoic magmatism in the West-Transbaikalian sector of the Central Asian orogenic belt.

(2). Quartz-molybdenum stockwork mineralization covers the apical part of the Pervomaisky massif and the adjacent biotite-quartz hornfels. New isotope-geochronological data on the age of zircons from granites, muscovite, and molybdenite from the ore zones have been obtained; they indicate the contingency of the processes of granite formation and ore deposition 119-128 million years ago.

(3). Molybdenite is the main ore mineral of the stockwork at the Pervomaiskoe deposit. The following mineral species are present as minor and rare: sulfides (pyrite, chalcopyrite, galena, sphalerite, bismuthin), sulfosalts (aikinite, salzburgite, sakuraite), complex oxides-molybdates, niobates (wulfenite, columbite), as well as beryl and accessory minerals (rutile, monazite, apatite, zircon).

(4). Analysis of FIs identifies periods of episodic boiling. Deposition of quartz-molybdenite veinlets occurred at the temperature of $\geq 314-186{ }^{\circ} \mathrm{C}$ from relatively low-salt solutions (6.3-12.7 wt. \% eq. $\mathrm{NaCl}$ ) containing $\mathrm{CO}_{2}, \mathrm{CH}_{4}$, and $\mathrm{N}_{2}$. Chlorides of $\mathrm{Na}, \mathrm{Ca}, \mathrm{K}$, and $\mathrm{Fe}$ prevail in the salt composition of the ore-forming fluids.

(5). The Mo content in FIs reaches $\sim 559 \mathrm{ppm}$ (average $28 \mathrm{ppm}$ ) in high-grade quartz-molybdenite veinlets and is up to $212 \mathrm{ppm}$ (average $25 \mathrm{ppm}$ ) in the low-grade veinlets.

(6). High-grade veinlets were formed by near-neutral solutions with a high content of Mo, S, F, Cu, and $\mathrm{Zn}$, while low-grade veinlets were deposited from alkaline fluids, revealing the $\mathrm{pH}$ of solutions as one of the factors of ore content.

Author Contributions: L.B.D. wrote the text of the article, conducted research and provided funding. B.B.D. assisted in research and sample preparation, as well as in editing and translating the text. X.-W.H. made Re-Os dating of molybdenite and helped with text editing and translation. N.V.B. analyzed the composition of fluid inclusions using the LA-ICP-MS method. V.B.K. conducted the U-Pb dating of granites by zircons using the LA-ICP-MS method. D.S.Y. carried out the Ar-Ar dating.

Funding: The work was performed within the state tasks of GIN SB RAS, IGC SB RAS, IGM SB RAS and Institute of Geochemistry, Chinese Academy of Sciences. The authors express great thanks to analysts E.V. Khodyreva and S.V. Kanakin, Ph.D for conducting electron microscopic analyzes (GIN SB RAS). The study has been performed with the funding by the Russian Foundation for Basic Research, grant No. 18-45-030002. The investigations has been conducted within the fundamental research framework of the GIN SB RAS (reg. number AAAA-A16-116122110027-2).

Conflicts of Interest: The authors declare no conflict of interest.

\section{References}

1. Gordienko, I.V.; Gorokhovsky, D.V.; Smirnova, O.K.; Lantseva, V.S.; Badmatsyrenova, R.A.; Orsoev, D.A. Dzhida Ore District: Geology, Structural and Metallogenic Regionalization, Genetic Types of Ore Deposits, Geodynamic Conditions of Their Formation, Forecast, and Outlook for Development. Geol. Ore Depos. 2018, 60, 3-37. [CrossRef] 
2. Reyf, F.G. Ore-Forming Potential of Granites and Conditions for Its Realization; Nauka: Moscow, Russia, 1990; p. 180. (In Russian)

3. Khodanovich, P.Y.; Smirnova, O.K. Tungsten Beresites and Local Forecast of Mineralization; Nauka Publ: Novosibirsk, Russia, 1991; p. 208. (In Russian)

4. Ontoev, D.O. Mineralization Staging and Zoning of Transbaikalian Deposits; Nauka Publ: Moscow, Russia, 1974; p. 241. (In Russian)

5. Khubanov, V.B.; Buyantuev, M.D.; Tsygankov, A.A. U-Pb dating of zircons from PZ3-MZ igneous complexes of Transbaikalia by sector-field mass spectrometry with laser sampling: Technique and comparison with SHRIMP. Russ. Geol. Geophys. 2016, 57, 190-205. [CrossRef]

6. Buyantuev, M.D.; Khubanov, V.B.; Vrublevskaya, T.T. U-Pb LA-ICP-MS dating of zircons from subvolcanics of the bimodal dyke series of the Western Transbaikalia: Technique, and evidence of the Late Paleozoic extension of the crust. Geodyn. Tectonophys. 2017, 8, 369-384. [CrossRef]

7. Griffin, W.L.; Powell, W.J.; Pearson, N.J.; O’Reilly, S.Y. GLITTER: Data reduction software for laser ablation ICP-MS. In Laser Ablation ICP-MS in the Earth Sciences: Current Practices and Outstanding Issues; Sylvester, P.J., Ed.; Mineralogical Association of Canada, Short Course Series: Vancouver, BC, Canada, 2008; Volume 40, pp. 308-311.

8. Ludwig, K.R. User's Manual for Isoplot 3.00: A Geochronological Toolkit for Microsoft Excel. Berkeley Geochronology Center. Spec. Publ. 2003, 4, 74.

9. Wiedenbeck, M.; Alle, P.; Corfu, F.; Griffin, W.L.; Meier, M.; Oberli, F.; van Quadt, A.; Roddick, J.C.; Spiegel, W. Three natural zircon standards for U-Th-Pb, Lu-Hf, trace element and REE analyses. Geostand. Newsl. 1995, 19, 1-23. [CrossRef]

10. Slama, J.; Kosler, J.; Condon, D.J.; Crowley, J.L.; Gerdes, A.; Hanchar, J.M.; Horstwood, M.S.A.; Morris, G.A.; Nasdala, L.; Norberg, N.; et al. Plesovice zircon-A new natural reference material for U-Pb and Hf isotopic microanalysis. Chem. Geol. 2008, 249, 1-35. [CrossRef]

11. Jackson, S.E.; Pearson, N.J.; Griffin, W.L.; Belousova, E.A. The application of laser ablation-inductively coupled plasma-mass spectrometry to in situ U-Pb zircon geochronology. Chem. Geol. 2004, 211, 47-69. [CrossRef]

12. Travin, A.V.; Yudin, D.S.; Vladimirov, A.G.; Khromykh, S.V.; Volkova, N.I.; Mekhonoshin, A.S.; Kolotilina, T.B. Thermochronology of the Chernorud granulite zone, Ol'khon Region, Western Baikal Area. Geochem. Int. 2009, 47, 1107-1124. [CrossRef]

13. Baksi, A.K.; Archibald, D.A.; Farrar, E. Intercalibration of ${ }^{40} \mathrm{Ar} /{ }^{39}$ Ar dating standards. Chem. Geol. 1996, 129, 307-324. [CrossRef]

14. Hunger, R.B.; Xavier, R.P.; Moreto, C.P.N.; Jian-Feng, G. Hydrothermal Alteration, Fluid Evolution, and Re-Os Geochronology of the GrotaFunda Iron Oxide Copper-Gold Deposit, Carajas Province (Para State), Brazil. Econ. Geol. 2018, 113, 1769-1794. [CrossRef]

15. Bodnar, R.J.; Vityk, M.O. Interpretation of microthermometric data for $\mathrm{H}_{2} \mathrm{O}-\mathrm{NaCl}$ fluid inclusions. In Fluid Inclusions in Minerals, Methods and Applications; de Vivo, B., Frezzotti, M.L., Eds.; Virginia Tech: Blacksburg, VA, USA, 1994; pp. 117-130.

16. Borisenko, A.S. Study of the salt composition of gas-liquid inclusions in minerals by the method of cryometry. Geol. Geophys. 1977, 8, 16-27. (In Russian)

17. Borovikov, A.A.; Goverdovskii, V.A.; Borisenko, A.S.; Bryanskii, N.V.; Shabalin, S.I. Composition and metal contents of ore-forming fluids of the Kalguty Mo-W(Be) deposit (Gorny Altai). Russ. Geol. Geophys. 2016, 57, 647-662. (In Russian) [CrossRef]

18. Bayanov, V.D. Late Mesozoic shashanite-latite series of the Dzhida ore district (South-Western Transbaikalia). Dokl. Earth Sci. 1994, 339, 374-377. (In Russian)

19. Ignatovich, V.I. Mineral and raw materials base of molybdenum. Razvedka I ohrana nedr 2007, 12, 37-43. (In Russian)

20. Malinovskii, E.P. Spatial localization of ore-forming fluid sources of Dzhida deposits by structural analysis data. Dzhida Ore District (Problems of Mineral Resources Development and Mining); Nauka Publ: Novosibirsk, Russia, 1984; pp. 116-126. (In Russian)

21. Povilaitis, M.M. Main Features of the Dzhida Molybdenum-Tungsten Deposit Mineralogy; USSR Academy of Sciences Publ: Moscow, Russia, 1960; p. 165. (In Russian) 
22. Povilaitis, M.M.; Mozgova, N.N.; Senderova, V.M. Bismuth minerals in the Dzhida molybdenum-tungsten deposit (Western Transbaikalia). Zap. Vsesoyuznogo mineralogicheskogo obshchestva 1969, 655-664. (In Russian)

23. Khodanovich, P.Y.Molybdenum-tungsten Deposits of the Dzhida Ore Fiel. Deposits of Transbaikalia; Geoinformmark Publ: Chita-Moscow, Russia, 1995; pp. 149-163. (In Russian)

24. Reyf, F.G.; Bazheev, E.D. Magmatic Process and Tungsten Mineralization; Nauka Publ: Novosibirsk, Russia, 1982; p. 158. (In Russian)

25. Reyf, F.G. The Conditions and Mechanisms of Formation of Granite Ore-magmatic Systems (according to thermobarogeochemical data); Publishing House IMGRE: Russia, Moscow, 2009; p. 498. (In Russian)

26. Stel'machonok, K.Z. On formation synchronicity of ore-hosting faults and molybdenum mineralization formation in the Pervomaisky stockwork field (Transbaikalia) and the causes of faulting. Dokl. Earth Sci. 1994, 337, 382-385. (In Russian)

27. Stel'machonok, K.Z. On the simultaneous formation of single-system veinlets in the molybdenite stockwork ore body of the Dzhida deposit (Transbaikalia). Dokl. Earth Sci. 1995, 341, 399-402. (In Russian)

28. Chernyshev, I.V.; Gol'tsman, Y.V.; Bairova, E.D.; Ivanova, G.F. Rb-Sr-geochronometry of sequential formation of granites, greysening and hydrothermal mineralization: Dzhida W-Mo deposit, Western Transbaikalia. Dokl. Earth Sci. 1998, 360, 537-540. (In Russian)

29. Redder, E. Fluid Inclusions in Minerals; Mir: Moscow, Russia, 1987; pp. 1-2. (In Russian)

30. Bodnar, R.J.; Vityk, M.O. Interpretation of Microthermometric Data for $\mathrm{H}_{2} \mathrm{O}-\mathrm{NaCl}$ Fluid Inclusions. In Fluid Inclusions in Minerals; De Vivo, B., Frezzotti, M.L., Eds.; Methods and Application: Pontignsno-Siena, Italy, 1994; pp. 117-130.

31. Kolonin, G.R. Experimental Studies of Sulfide and Silicate Systems; Collection of Scientific Papers; IGG SB AS USSR: Novosibirsk, Russia, 1981; p. 80. (In Russian)

32. Ripp, G.S.; Smirnova, O.K.; Izbrodin, I.A.; Lastochkin, E.I.; Rampilov, M.O.; Posokhov, V.F. An Isotope Study of the Dzhida Mo-W Ore Field (Western Transbaikalia, Russia). Minerals 2018, 8, 546. [CrossRef]

33. Naumov, V.B.; Dorofeeva, V.A.; Mironova, O.F. Physicochemical parameters of the origin of hydrothermal mineral deposits: Evidence from fluid inclusions. IV. Copper and molybdenum deposits. Geochem. Int. 2017, 55, 711-725. [CrossRef]

34. Sharp, Z.D.; Gibbons, J.A.; Maltsev, O.; Atudorei, V.; Pack, A.; Sengupta, S.; Shock, E.L.; Knauth, L.P. A calibration of the triple oxygen isotope fractionation in the $\mathrm{SiO} 2-\mathrm{H} 2 \mathrm{O}$ system and applications to natural samples. Geochim. Cosmochim. Acta 2016, 186, 105-119. [CrossRef]

35. Zheng, Y.-F. Calculation of oxygen isotope fractionation in anhydrous silicate minerals. Geochim. Cosmochim. Acta 1993, 57, 1079-1091. [CrossRef]

36. Yarmolyuk, V.V.; Kovalenko, V.I.; Ivanov, V.G. The intraplate Late Mesozoic-Cenozoic volcanic province of Asia-A projection of the hot mantle field. Geotectonics 1995, 29, 395-421. 